\title{
Effect of selected factors (body weight, age, parity, litter size and temperament) on the entrance order into the milking parlour of Lacaune ewes, and its relationship with milk production
}

\author{
K. Libis-Márta, P. Póti, I. Egerszegi, Á. Bodnár ${ }^{1}$ and F. Pajor \\ Hungarian University of Agriculture and Life Sciences, 2100 Gödöllő, Páter Károly 1, Hungary
}

KEY WORDS: entrance order, milk, milking parlour, productivity, sheep, temperament

Received: 25 January 2021

Revised: 25 March 2021

Accepted: 13 April 2021

\begin{abstract}
Aims of this study were to evaluate the effect of body weight, age, parity, litter size and temperament on the Lacaune ewes' milk production (length of lactation (LL), total milk yield (TMY), standard milk yield (milk between the $60^{\text {th }}$ and $150^{\text {th }}$ day of lactation (SMY)) and daily milk yield (DMY)) and the entrance order into the milking parlour. The effect of entrance order (the first vs the last group) on the milk production (LL, TMY, SMY, DMY) and composition from 143 ewes was also analysed. The milking period started on the mid of March, and lasted for 229 days on average, and a two-platform milking parlour was used. Moreover, out of the total number of 143 animals, 22 ewes were selected that entered the parlour as the first group (FG) and 18 ewes - as the last group (LG), in all observations. The order of sheep at the entrance to the milking parlour was observed in four periods. Parity and temperament affected the milk production traits. Furthermore, the ewes' entrance order was significantly affected by their body weight and temperament. Entrance order into milking parlour did not exert an effect on the LL and milk composition; however, FG had significantly higher TMY, SMY and DMY in comparison to LG as well as daily milk fat and protein yield. These data prove that calmer and heavier ewes entered the milking parlour earlier than other ewes; moreover, a later entrance into the milking parlour may be associated with reduced milk production.
\end{abstract}

${ }^{1}$ Corresponding author:

e-mail: bodnar.akos@uni-mate.hu production is having a chance to become a branch providing workplaces and marketable products.

It is well known, that many factors, such as breed, feeding or parity, have an influence on the quantity and the composition of sheep milk. Also, evaluating the behaviour of the animals is becoming more and more important, parallel to the increasing frequency of intensive milk production. Behaviour during milkings, such as entrance order into the milking parlour and temperament are associated with milk production. There are several studies about the milk production of ewes entering in the first and the last groups into the parlour. It was determined that ewes entering 
into the parlour in the first group had a higher milk yield than those, who entered in the last group, in contrast, milk composition was not related to the entrance order into the milking parlour (Villagrá et al., 2007; Mačuhová et al., 2017).

In addition, several studies reported previously that temperament was linked with the total milk yield in dairy sheep (Murray et al., 2009; Pajor et al., 2010; Tóth et al., 2017a). According to these results, calmer ewes produced more milk than nervous ones.

Preference for a given milking stand is only temporal in sheep (Keszthelyi and Maros, 1992; Polikarpus et al., 2015; Nedeva et al., 2019), in case of entrance order into the milking parlour in two consecutive days it shows a very strong correlation $\left(\mathrm{r}^{2}=96 \%, P<0.001\right)$. As an opposite, in the case of long-term consistency of the entrance order into the milking parlour Wasilewski (1999) did not find a significant relationship, thus concluded that entrance order changes dynamically (lasting only for at least a week), it is not static, neither permanent.

There are fewer studies about factors influencing the entrance order into the milking parlour. According to Margetínová et al. (2003), age has an influence on the entrance order into the milking stand. There was no relation between the parity and the entrance order into the milking parlour, according to Mačuhová et al. (2017). Nevertheless, to the best of our knowledge, there is no information available about the effect of litter size, body weight and temperament on the entrance order into the milking parlour of ewes.

The aims of our study were as follows: (i) to evaluate the effect of certain factors (body weight, age, parity, litter size and temperament) on the Lacaune ewes' milk production traits (length of lactation, total milk yield, standard milk yield and daily milk yield), (ii) to examine the effect of abovementioned factors on the entrance order into the milking parlour, and (iii) to analyse the effect of the entrance order (the first $v s$ the last group into milking parlour) on the milk production parameters and composition (fat and protein content). We hypothesized that calmer animals enter earlier into the milking parlour than the nervous ones, and that in the first-entrance group ewes have higher milk production in comparison to the last-entrance group.

\section{Material and methods}

\section{Experimental design}

The sheep farm is located in Mórichida $\left(47^{\circ} 29^{\prime} 10.5^{\prime \prime} \mathrm{N}\right.$ and $\left.17^{\circ} 25^{\prime} 18.4^{\prime \prime} \mathrm{E}\right)$, Györ-MosonSopron County (Hungary) and has been breeding milk-producing Lacaune breed since 1995. Data were recorded from 143 milking ewes, selected from a herd of 300 ewes. Ewes were lambing once a year, in the end of January - the beginning of February. Lambs were weaned on the $50^{\text {th }}$ day on average. Milking was started on $14^{\text {th }}$ of March and lasted for 228 days on average. Individual milk production (total and standard milk yield) of the ewes has been calculated based on daily milk recording per month, made by the Sheep Performance Testing Codex of the Hungarian Sheep and Goat Breeders' Association (HSGBA, 2013) and following the guidelines of the International Committee for Animal Recording (ICAR, 2018). Standard milk yield means the amount of milk between the $60^{\text {th }}$ and $150^{\text {th }}$ day of lactation (HSGBA, 2013). Mean total milk yield and lactation period per ewe were $198 \mathrm{~kg}$ and 229 days. Animals were between 2-6 years of age and 1-5 parities. Hungarolact milking system with $2 \times 24$ parallel stands was applied twice a day, at 5:00 and 17:00. Ewes spent $10 \mathrm{~min}$ in the milking stands on average, meanwhile could consume concentrate. Animals were kept in a half-intensive system; for 190 days (from April till November) grazing on pasture, supplemented with $400 \mathrm{~g}$ concentrate $\left(\mathrm{NE}_{1}: 7.1 \mathrm{MJ} / \mathrm{kg}\right.$ dry matter $(\mathrm{DM})$; crude protein: $180 \mathrm{~g} / \mathrm{kg} \mathrm{DM}$, containing vitamins $\mathrm{A}, \mathrm{D}_{3}$, E) and ad libitum alfalfa hay $\left(\mathrm{NE}_{1}: 5.1 \mathrm{MJ} / \mathrm{kg} \mathrm{DM}\right.$; crude protein: $189 \mathrm{~g} / \mathrm{kg} \mathrm{DM}$ ). The main species were Lolium perenne, Poa pratensis, Festuca rubra and Lotus corniculatus on the pasture. Commercial trace-mineralized salt blocks were free of choice for animals.

Entrance order into milking parlour (referred to as entrance order) was recorded four times, on the $48^{\text {th }}, 74^{\text {th }}, 103^{\text {rd }}$ and $132^{\text {nd }}$ day of lactation at morning and evening milkings, a day before of individual milk recording according to HSGBA; ewes were milked in 6 groups. After entrance order recording, the temperament of the ewes was also studied, besides, immediately after temperament scoring milk samples were taken from all observed ewes.

Temperament was determined based on the behaviour in the milking stand by observation and scored on a 1 to 5 scale (Budzynska et al., 2005) when the most nervous animals were ranked 1, while the calmest ones 5 (1\# very nervous, continual and vigorous stepping and kicking; $2 \#$ continual and vigorous stepping without kicking; $3 \#$ occasionally vigorous leg movements; $4 \#$ quiet standing with few slight leg movements; $5 \#$ very quiet, no leg movements). The individual daily two samples were combined before analysis. Milk composition (fat and 
protein) was analysed by LactoScope ${ }^{\mathrm{TM}}$ (Delta Instruments Ltd., Drachten, The Netherlands) instrument.

Adult age body weight of ewes (referred to as body weight) was measured at age of 28 months according to the Sheep Performance Testing Codex of the Hungarian Sheep and Goat Breeders' Association (HSGBA, 2013). Mean body weight of investigated ewes was $62 \mathrm{~kg}$. Ewes were assigned to two different groups according to their body weight: low body weight $(<62 \mathrm{~kg}, \mathrm{LBW})$ and high body weight ( $\geq 62 \mathrm{~kg}, \mathrm{HBW}$ ) groups.

After the experiments were finished, 22 ewes were selected from the total number of 143 animals that went as the first group (FG) in all observations, and 18 ewes that always entered the parlour as the last group (LG). Both groups were compared for the evaluated factors (age, parity, litter size, body weight and temperament), and milk production (daily milk yield, total milk yield, standard milk yield and length of lactation) and composition (percentage of fat and protein, daily fat and protein yield) parameters.

\section{Statistical analysis}

Statistical analysis was made by SPSS 25.0 software (IBM Corporation, Armonk, NY, USA). The distribution of the data was analysed by Kolmogorov-Smirnov test. Before the statistical analysis, the numbers of ewes with temperament scores 1 and 2 were merged into one group $(1+2)$, because of their low numbers $(n=3$ and $n=5)$. where: $\mathrm{Y}_{i j k l m}$ - trait analysed; $\mu$ - mean, $\mathrm{A}_{i}-$ effect of body weight (fix effect: 2 classes), $\mathrm{B}_{j}$ - effect of age (fix effect: 5 classes), $\mathrm{C}_{k}$ - effect of parity (fix effect: 5 classes), $\mathrm{D}_{l}$ - effect of litter size (fix effect: 3 classes), $\mathrm{E}_{m}$ - effect of temperament (fix effect: 4 classes) and $\mathrm{e}_{i j k l m}$ - error. Differences between groups were analysed by Tukey test.

The significance of differences of the evaluated factors and milk production traits of the ewes by entrance order into milking parlour (the first $v s$ the last group) was assessed by F-test and t-test, milk composition parameters (fat and protein content, daily fat and protein yield) were analysed by repeated-measures GLM, and in case of temperament Mann-Whitney U test was used. The consistency of the observations on entrance order into the milking parlour of ewes was studied by Kendall's W test.

\section{Results}

The average age and parity of ewes, length of milking period, total milk yield (TMY), standard milk yield (SMY) and daily milk yield (DMY) as well as fat and protein content are shown in Table 1. The mean age of ewes was 4.5 years, the mean parity was 2.87 and the mean length of lactation was 229 days. TMY, SMY and DMY were 198, $123.5 \mathrm{~kg}$ and $0.83 \mathrm{~kg}$, respectively. The mean values of fat and protein content were 7.78 and $5.78 \%$, respectively.

The effect of body weight, age, parity, litter size and temperament on milk production traits of ewes

Table 1. Descriptive statistics of ewes' age and parity, as well as milk production parameters in Lacaune herd $(n=143)$

\begin{tabular}{|c|c|c|c|c|c|c|c|c|}
\hline Indices & Age & Parity & $\begin{array}{l}\text { Lactation } \\
\text { length, day }\end{array}$ & $\begin{array}{l}\text { Total milk yield, } \\
\text { kg }\end{array}$ & $\begin{array}{l}\text { Standard milk } \\
\text { yield, } \mathrm{kg}^{*}\end{array}$ & $\begin{array}{l}\text { Daily milk yield, } \\
\text { kg }\end{array}$ & $\begin{array}{l}\text { Fat, } \\
\%\end{array}$ & $\begin{array}{l}\text { Protein, } \\
\%\end{array}$ \\
\hline Mean & 4.50 & 2.87 & 229.18 & 197.72 & 123.47 & 0.83 & 7.78 & 5.78 \\
\hline $\mathrm{SD}$ & 1.56 & 1.24 & 7.84 & 34.39 & 30.82 & 0.15 & 0.85 & 0.19 \\
\hline Minimum & 1.00 & 1.00 & 199.00 & 126.20 & 66.90 & 0.55 & 5.93 & 5.29 \\
\hline Maximum & 6.00 & 6.00 & 288.00 & 272.60 & 194.30 & 1.15 & 9.96 & 6.25 \\
\hline
\end{tabular}

* standard milk yield $=$ milk production between the $60^{\text {th }}$ and $150^{\text {th }}$ day of lactation

In the study, the effect of body weight $(<62 \mathrm{~kg}$ and $\geq 62 \mathrm{~kg}$ ), age (two, three, four, five and six years), parity (first, second, third, fourth and fifth), litter size (single, twin and triplet birth) and temperament (score $1+2$, score 3 , score 4 and score 5 ) on milk production traits (lactation length, total milk yield, standard milk yield and daily milk yield) and entrance order into the milking parlour of ewes (there were four observations) were evaluated. The general linear model (GLM) procedure was used to analyse variance according to the formula below:

$$
\mathrm{Y}_{i j k m}=\mu+\mathrm{A}_{i}+\mathrm{B}_{j}+\mathrm{C}_{k}+\mathrm{D}_{l}+\mathrm{E}_{m}+\mathrm{e}_{i j k m},
$$

are shown in Table 2. In this study, body weight, age and litter size of the ewes had no significant effect on the milk yields (TMY, SMY and DMY). In contrast, parity and temperament had markedly affect the milk production traits of ewes. The ewes in the third parity had significantly higher TMY $(209 \mathrm{~kg})$, SMY $(129 \mathrm{~kg})$ and DMY $(0.91 \mathrm{~kg})$ in comparison to ewes in the first $(170,102$ and $0.76 \mathrm{~kg}$, respectively) or fifth parity $(185,100$ and $0.80 \mathrm{~kg}$, respectively). Moreover, the calmer ewes had higher TMY $(209 \mathrm{~kg})$, SMY $(125 \mathrm{~kg})$ and DMY $(0.92 \mathrm{~kg})$ than nervous ones $(182,118$ and $0.81 \mathrm{~kg}$, respectively). 
Table 2. Main effects of body weight, age, parity number, litter size and temperament on milk production traits of Lacaune ewes $(n=143)$ $(\mathrm{LSM} \pm \mathrm{SEM})$

\begin{tabular}{|c|c|c|c|c|c|c|c|}
\hline Indices & $\mathrm{n}$ & $\begin{array}{l}\text { Length of } \\
\text { lactation, day }\end{array}$ & $\begin{array}{l}\text { Total milk yield, } \\
\mathrm{kg}\end{array}$ & $\begin{array}{l}\text { Standard milk } \\
\text { yield, } \mathrm{kg}\end{array}$ & $\begin{array}{l}\text { Daily milk yield, } \\
\text { kg }\end{array}$ & Fat, $\%$ & Protein, \% \\
\hline \multicolumn{8}{|c|}{ Body weight } \\
\hline LBW & 65 & 231.62 & 184.64 & 112.46 & 0.81 & 7.83 & 5.71 \\
\hline HBW & 78 & 230.95 & 194.66 & 116.73 & 0.85 & 7.87 & 5.78 \\
\hline$P$-value & & 0.694 & 0.122 & 0.481 & 0.158 & 0.812 & 0.103 \\
\hline \multicolumn{8}{|l|}{ Age } \\
\hline 2 & 15 & 234.68 & 189.58 & 105.61 & 0.83 & 7.91 & 5.75 \\
\hline 3 & 41 & 230.41 & 195.56 & 116.91 & 0.85 & 7.95 & 5.76 \\
\hline 4 & 7 & 231.67 & 189.20 & 125.30 & 0.82 & 8.38 & 5.77 \\
\hline 5 & 18 & 230.22 & 190.81 & 114.54 & 0.84 & 7.35 & 5.69 \\
\hline 6 & 62 & 229.45 & 183.12 & 110.60 & 0.81 & 7.67 & 5.77 \\
\hline$P$-value & & 0.393 & 0.701 & 0.594 & 0.775 & 0.184 & 0.733 \\
\hline \multicolumn{8}{|c|}{ Parity number } \\
\hline 1 & 17 & 232.21 & $170.03^{a}$ & $101.96^{a}$ & $0.76^{a}$ & 7.75 & 5.60 \\
\hline 2 & 53 & 230.28 & $194.12^{b}$ & $120.35^{b}$ & $0.85^{b}$ & 7.78 & 5.75 \\
\hline 3 & 24 & 232.34 & $209.44^{b}$ & $128.94^{b}$ & $0.91^{b}$ & 7.54 & 5.82 \\
\hline 4 & 31 & 230.55 & $190.08^{\mathrm{ab}}$ & $121.72^{\mathrm{ab}}$ & $0.83^{\mathrm{ab}}$ & 7.95 & 5.77 \\
\hline 5 & 18 & 231.04 & $184.61^{\mathrm{ab}}$ & $100.00^{a}$ & $0.80^{\mathrm{a}}$ & 8.25 & 5.79 \\
\hline$P$-value & & 0.828 & 0.009 & 0.011 & 0.010 & 0.179 & 0.097 \\
\hline \multicolumn{8}{|l|}{ Litter size } \\
\hline 1 & 38 & 231.25 & 188.61 & 116.38 & 0.83 & 7.82 & 5.74 \\
\hline 2 & 97 & 230.47 & 185.99 & 119.38 & 0.82 & 7.91 & 5.76 \\
\hline 3 & 8 & 232.14 & 194.36 & 108.01 & 0.85 & 7.84 & 5.75 \\
\hline$P$-value & & 0.815 & 0.784 & 0.635 & 0.843 & 0.850 & 0.879 \\
\hline \multicolumn{8}{|c|}{ Temperament } \\
\hline $1+2$ & 8 & 233.69 & $181.70^{\mathrm{a}}$ & $117.86^{\mathrm{ab}}$ & $0.81^{a b}$ & 7.61 & 5.73 \\
\hline 3 & 17 & 229.71 & $170.10^{\mathrm{a}}$ & $97.18^{a}$ & $0.74^{a}$ & 8.39 & 5.77 \\
\hline 4 & 56 & 231.43 & $197.52^{b}$ & $117.96^{b}$ & $0.86^{b}$ & 7.52 & 5.76 \\
\hline 5 & 62 & 230.31 & $209.28^{b}$ & $125.37^{c}$ & $0.92^{c}$ & 7.92 & 5.73 \\
\hline$P$-value & & 0.614 & 0.000 & 0.012 & 0.000 & 0.283 & 0.913 \\
\hline SEM & & 1.714 & 6.548 & 6.162 & 0.028 & 0.205 & 0.049 \\
\hline
\end{tabular}

LBW - low body weight ( $<62 \mathrm{~kg}$ ); HBW - high body weight ( $\geq 62 \mathrm{~kg}$ ); abc - means in the same column with different superscripts are significantly different at $P<0.05$

Moreover, none of the examined factors affected the fat and protein content of the milk.

The effect of body weight, age, parity, litter size and temperament on the entrance order of ewes is presented in Table 3 . In the present study, age, parity and litter size of the ewes had no significant effect on the entrance order, in all observations, whilst, body weight and temperament had a significant influence on the entrance order of ewes. Based on the body weight of the ewes, 65 animals were below $(<62 \mathrm{~kg}, \mathrm{LBW})$ and 78 animals were over $(\geq 62 \mathrm{~kg}$, HBW) the average body weight of the experimental animals. The mean body weight in the groups was 56 and $68 \mathrm{~kg}$, respectively. The entrance order value in the LBW was 3.62 , while in HBW it was 3.27. We could observe, that the entrance order of the ewes was continuously decreased parallel to the increasing of the temperament scores. We can conclude that the more nervous (scored 1-2-3) animals entered into the milking parlour later than the calmer ones (scored 5). In our study, 43.4\% $(n=62)$ of Lacaune ewe got 5 points, $39.2 \%(n=56)$ of ewes got $4,11.9 \%(n=17)$ of ewes got 3 and $5.6 \%(n=8)$ of ewes got 1 and 2 points in the temperament test, respectively.

The entrance order of the ewes into the milking parlour was observed four times during the study. The long-term consistency was low among the entrance orders into the parlour on the four occasions according to Kendall's W test ( $\mathrm{W}<0.030 ; P<0.05$ ).

The effect of the entrance order on the milk production traits of the ewes is presented in Table 4. Based on the entrance order observation, it can be stated that 22 ewes entered the milking parlour first (first group, FG) and 18 ewes as the last ones (last group, LG) in all observations. A significant 
Table 3. Main effects of body weight, age, parity number, litter size and temperament on entrance order into milking parlour of Lacaune ewes $(n=143)(L S M \pm S E M)$

\begin{tabular}{|c|c|c|c|c|c|c|}
\hline \multirow{2}{*}{ Indices } & \multirow{2}{*}{$n$} & \multicolumn{5}{|c|}{ Observations } \\
\hline & & 1 & 2 & 3 & 4 & total \\
\hline \multicolumn{7}{|c|}{ Body weight } \\
\hline LBW & 65 & $3.78^{\mathrm{b}}$ & $4.24^{b}$ & $4.33^{b}$ & 3.99 & $4.09^{b}$ \\
\hline HBW & 78 & $3.09^{\mathrm{a}}$ & $3.21^{\mathrm{a}}$ & $3.62^{\mathrm{a}}$ & 3.34 & $3.32^{\mathrm{a}}$ \\
\hline$P$-value & & 0.022 & 0.003 & 0.039 & 0.058 & 0.003 \\
\hline \multicolumn{7}{|l|}{ Age } \\
\hline 2 & 15 & 3.15 & 2.89 & 3.54 & 3.24 & 3.21 \\
\hline 3 & 41 & 3.81 & 3.75 & 4.01 & 4.09 & 3.92 \\
\hline 4 & 7 & 3.69 & 4.43 & 5.26 & 4.03 & 4.35 \\
\hline 5 & 18 & 2.76 & 3.56 & 3.30 & 3.35 & 3.24 \\
\hline 6 & 62 & 3.78 & 4.00 & 3.75 & 3.62 & 3.79 \\
\hline$P$-value & & 0.164 & 0.242 & 0.221 & 0.417 & 0.122 \\
\hline \multicolumn{7}{|c|}{ Parity number } \\
\hline 1 & 17 & 3.62 & 4.27 & 4.16 & 3.84 & $3.97^{\mathrm{ab}}$ \\
\hline 2 & 53 & 3.58 & 4.05 & 3.96 & 3.81 & $3.85^{\mathrm{ab}}$ \\
\hline 3 & 24 & 2.68 & 2.92 & 3.23 & 2.67 & $2.87^{a}$ \\
\hline 4 & 31 & 3.55 & 3.51 & 3.74 & 3.99 & $3.70^{\mathrm{ab}}$ \\
\hline 5 & 18 & 3.76 & 3.90 & 4.77 & 4.01 & $4.11^{\mathrm{b}}$ \\
\hline$P$-value & & 0.153 & 0.237 & 0.096 & 0.054 & 0.035 \\
\hline \multicolumn{7}{|l|}{ Litter size } \\
\hline 1 & 38 & 3.36 & 4.01 & 4.02 & 3.94 & 3.83 \\
\hline 2 & 97 & 3.62 & 3.76 & 4.05 & 3.81 & 3.81 \\
\hline 3 & 8 & 3.33 & 3.41 & 3.85 & 3.24 & 3.46 \\
\hline$P$-value & & 0.611 & 0.616 & 0.965 & 0.669 & 0.819 \\
\hline \multicolumn{7}{|c|}{ Temperament } \\
\hline $1+2$ & 8 & $4.06^{\text {bc }}$ & $4.22^{\mathrm{ab}}$ & $4.35^{\mathrm{ab}}$ & $3.73^{a b}$ & $4.09^{b c}$ \\
\hline 3 & 17 & $4.21^{\mathrm{c}}$ & $4.32^{b}$ & $4.53^{b}$ & $4.49^{b}$ & $4.39^{\circ}$ \\
\hline 4 & 56 & $3.20^{\mathrm{b}}$ & $3.51^{\mathrm{ab}}$ & $3.90^{\mathrm{ab}}$ & $3.70^{b}$ & $3.58^{b}$ \\
\hline 5 & 62 & $2.29^{a}$ & $2.87^{a}$ & $3.11^{\mathrm{a}}$ & $2.74^{a}$ & $2.75^{\mathrm{a}}$ \\
\hline$P$-value & & 0.000 & 0.006 & 0.005 & 0.001 & 0.000 \\
\hline SEM & & 0.302 & 0.345 & 0.347 & 0.346 & 0.261 \\
\hline
\end{tabular}

LBW - low body weight ( $<62 \mathrm{~kg}$ ); HBW - high body weight $(\geq 62 \mathrm{~kg}$ ); abc - means in the same column with different superscripts are significantly different at $P<0.05$

Table 4. Mean values of body weight, age, parity, litter size, temperament and milk production parameters of ewes by milking group (entrance order into parlour as the first and as the last group)

\begin{tabular}{|c|c|c|c|c|c|}
\hline \multirow{2}{*}{ Indices } & \multicolumn{2}{|c|}{ First group $(n=22)$} & \multicolumn{2}{|c|}{ Last group $(n=18)$} & \multirow{2}{*}{$P$-value } \\
\hline & mean & SD & mean & SD & \\
\hline Body weight, $\mathrm{kg}$ & 63.07 & 9.65 & 57.13 & 7.57 & 0.040 \\
\hline Age, year & 4.35 & 1.73 & 4.56 & 1.51 & 0.688 \\
\hline Parity, number & 2.94 & 0.97 & 3.11 & 1.90 & 0.716 \\
\hline Litter size, lambs per ewe & 1.88 & 0.49 & 1.78 & 0.44 & 0.506 \\
\hline Temperament, score & 4.59 & 0.80 & 3.56 & 1.01 & $<0.001$ \\
\hline Lactation length, day & 228.52 & 6.77 & 229.58 & 5.44 & 0.648 \\
\hline Total milk yield, $\mathrm{kg}$ & 203.10 & 36.28 & 168.34 & 38.95 & 0.019 \\
\hline Standard milk yield, $\mathrm{kg}$ & 132.1 & 35.28 & 102.0 & 37.73 & 0.034 \\
\hline Daily milk yield, $\mathrm{kg}$ & 0.89 & 0.15 & 0.74 & 0.17 & 0.017 \\
\hline Fat, $\%$ & 7.84 & 0.89 & 7.52 & 0.74 & 0.348 \\
\hline Daily fat yield, $g$ & 69.79 & 7.93 & 55.68 & 1.59 & $<0.001$ \\
\hline Protein, \% & 5.81 & 0.18 & 5.74 & 0.14 & 0.299 \\
\hline Daily protein yield, $\mathrm{g}$ & 51.75 & 1.59 & 42.49 & 1.05 & $<0.001$ \\
\hline
\end{tabular}


difference was found in the body weight and temperament scores between the FG and LG. Entrance order did not affect the length of lactation; similar values (around 229 days) were found in FG and LG. However, the entrance order had a significant effect on TMY. Ewes in the FG produced $203 \mathrm{~kg}$ milk, while ewes in the LG produced $168 \mathrm{~kg}$ milk $(P<0.05)$. The difference between the averages of the two groups is highly pronounced $-35 \mathrm{~kg}$. The same tendency was visible in the case of DMY and SMY. Ewes in the FG produced significantly $(P<0.05)$ more $(0.89$ and $132 \mathrm{~kg}$, respectively for DMY and SMY) milk, than the ewes in the LG $(0.74$ and $102 \mathrm{~kg})$. Furthermore, there was no difference in milk fat and protein content between FG (7.84 and 5.81\%) and LG (7.52 and 5.74\%). In contrast, the daily milk fat and protein yield were significantly higher in FG (69.8 and $51.8 \mathrm{~g}$ ) than LG (55.7 and $42.5 \mathrm{~g} ; P<0.001)$.

\section{Discussion}

The daily milk yield and the length of lactation of the studied animals were more advantageous in comparison to earlier reports (Oravcová et al., 2018; Makovický et al., 2019; Margetín et al., 2020). Milk production records of the population studied were highly above the official Hungarian data (lactation milk yield: $153.6 \mathrm{~kg}$, length of lactation: 126 days) (HSGBA, 2018). Parameters of milk fat and protein were in concordance with earlier reports (Park et al., 2006; Makovický et al., 2014; Chay-Canul et al., 2020; Margetín et al., 2020).

The body weight had no significant effect on milk production (TMY, SMY and DMY), and similar results had been reported earlier by Marie et al. (1996). In contrast, a significant difference was observed between the two body weight groups regarding their TMY; ewes with higher body weight produced more milk than others (Ángeles Hernández et al., 2017). The age of ewes had no significant effect on milk production traits. It was in line with the Flbeearlier report of Tóth et al. (2017b). The parity had a great effect on milk production of the ewes; animals in the first or fifth parity had lower TMY, SMY and DMY than ewes in the second or third parities. This was in concordance with the findings of Robles Jimenez et al. (2020), who reported the highest milk yield in the second, third and fourth parities. The litter size had no significant effect on the milk production traits, which is in line with the results published by Oravcová et al. (2006). However, Robles Jimenez et al. (2020) found a signifi- cant effect of litter size on TMY of ewes. Finally, temperament had a significant effect on TMY, SMY and DMY of ewes. The calm (score 5) ewes had the highest TMY, SMY and DMY in comparison to nervous ones. Previously several authors reported high differences between the TMY of animals with calm and nervous temperament (Murray et al., 2009; Pajor et al., 2010; Tóth et al., 2017a). Our results show that body weight, age, parity, litter size and temperament did not affect the percentages of milk fat or protein contents. These results concordance with those of Oravcová et al. (2007), Othmane et al. (2002) and Tóth et al. (2017a).

The body weight of ewes had a significant effect on the entrance order of animals; the lowest entrance order value was found in the higher body weight group in comparison to animals with lower body weight, in all observations. In this way, LBW ewes entered significantly later into the milking parlour than HBW ewes. Age had no effect on the entrance order of ewes. On the contrary, Margetínová et al. (2003) in goats, while Dimitrov et al. (2012) in sheep showed that age affected the entrance order into the milking stand significantly. Parity did not affect the entrance order of ewes, except only in the total value of the entrance order. Otherwise, in all observations, the entrance order was not influenced by parity, nevertheless, the tendency was similar; ewes in the fifth parity had a higher value of entrance order than animals in the third parity. Previously Mačuhová et al. (2017) did not found a significant effect of parity on the entrance order into the milking parlour. The litter size had no effect on the entrance order of ewes in all observations. However, entrance order based on litter size differed only slightly, but there was no significant effect of litter size on the entrance order into the milking parlour. Ewes with triplets were somewhat earlier entered into the milking parlour in comparison to ewes with single lamb or with twins. Temperament had a significant effect on the entrance order of ewe in all observations; the calmer animals were entered earlier into the milking parlour in comparison to nervous ones. Most of the ewes $(\mathrm{n}=118,82 \%$ from the total) in the present study belonged to the calm temperament category (scored 4 and 5). The distribution of temperament traits was quite similar in previous studies; Szentléleki et al. (2015) found that $90 \%$ of the dairy cows were calm, while Tóth et al. (2017a) proved $85 \%$ of the dairy sheep being calm.

Based on these observations, the long-term consistency of the entrance order was analysed. Our 
results were in concordance with the earlier report by Wasilewski (1999), who concluded that long-term consistency (more than a one-week period) of the entrance order into the milking parlour is dynamically changing ( $W$ value of investigated flock was $<0.025$ ).

In this study, the ewes in FG were calmer and had higher body weight than LG. These results suggested that temperament is associated with body weight. Previously it was reported that calmer ewes had higher body weight in comparison to temperamental animals (Bokor et al., 2016). In addition, earlier it was reported that calmer ewes produced more milk than temperamental ones (Murray et al., 2009; Tóth et al., 2017a). Moreover, Ángeles Hernández et al. (2017) reported that ewes with high body weight had consistently higher TMY than ewes with low body weight. In contrast, no significant difference was observed between the two groups regarding their age, parity and litter size. The entrance order had significantly affected the milk yields (TMY, DMY and SMY). Our results were in concordance with Margetínová et al. (2003), Villagrá et al. (2007) and Mačuhová et al. (2017) who all suggested that animals milked in the first group produced higher milk yield than those which were milked in the last group. The milk composition was not affected by the entrance order, which was in concordance with earlier reports (Villagrá et al., 2007; Mačuhová et al., 2017). In contrast, daily fat and protein yield were higher in FG than LG. The milk fat protein content and yield are important for dairy sheep farmers because it is well known that these parameters greatly influence the cheese composition and cheese yield.

\section{Conclusions}

It was found, that the entrance order into the milking parlour of ewes was significantly affected by their body weight and temperament. Calmer and heavier ewes entered into the milking parlour earlier than others. Moreover, the entrance order into the milking parlour had a significant influence on the milk production; a later entrance into the milking parlour may be associated with a reduced total and daily milk yield as well as daily milk protein and fat yield. The entrance order could be used as an indicator of ewes' milking ability throughout the lactation period.

\section{Acknowledgments}

This study was financed by EFOP-3.6.3VEKOP-16-2017-00008 project. The project was supported by the European Union, co-supported by the European Social Fund.

\section{Conflict of interest}

The authors declare that there is no conflict of interest.

\section{References}

Ángeles Hernández J.C., Schilling S.R., Vera Arias M.A., Echeverría Pérez R.A., Castelán-Ortega O.A., Ramírez Pérez A.H., Ronquillo M.G., 2017. Effect of live weight pre- and postlambing on milk production of East Friesian sheep. Ital. J. Anim. Sci. 17, 184-194, https://doi.org/10.1080/182805 1X.2017.1349536

Bokor B., Póti P., Abayné E.H., Kerti A., Szabó C., Morlin Z., Pajor F., 2016. Effect of temperament on some blood biochemical parameters and growing traits of lambs during fattening. J. Anim. Res. 6, 367-370, https://doi.org/10.5958/2277940X.2016.00032.2

Budzynska B., Ceglinska A., Kamieniak J., Krupa W., Sapula M., 2005. Behaviour of dairy cows during premilking udder preparation. In: P. Juhás, K. Vavrišinová, I. Vavríková (Editors). Book of Abstracts of the 4th International Congress on Ethology in Animal Production. Nitra (Slovak Republic). Slovak Agricultural University, Nitra (Slovak Republic), pp. 33-35

Chay-Canul A.J., Parra-Bracamonte G.M., Lopez-Villalobos N., Herrera-Ojeda J.B., Magaña-Monforte J.G., PenicheGonzález I.N., Herrera-Camacho J., García-Herrera R., 2020. Milk yield and composition of Katahdin and Pelibuey ewes in tropical conditions. J. Anim. Feed Sci. 29, 352-357, https:// doi.org/10.22358/jafs/129966/2020

Dimitrov I., Stancheva N., Staikova G., Peeva J., Vasilev V., Apostolov A., 2012. Assessment of level of fear susceptibility during machine milking in dairy sheep of different ages and temperament. Bulg. J. Agric. Sci. 18, 482-486

FAO (Food and Agriculture Organization of the United Nations), 2020. http://www.fao.org/faostat/en/\#data (accessed on 2020.09.14.)

Fenyvessy J., Csanádi J., 1999. Nutritional assessment of milk components of small ruminants (sheep, goats) (in Hungarian: A kiskérődzők (juh, kecske) tejalkotórészeinek táplálkozási megítélése). Tejgazdaság 59, 23-26

HSGBA (Hungarian Sheep and Goat Breeders' Association), 2013. Sheep Performance Testing Codex, $9^{\text {th }}$ Edition. Budapest (Hungary) (https://mjksz.hu, accessed on 2020.10.01.)

HSGBA (Hungarian Sheep and Goat Breeders' Association), 2018. Results of breeding and production of Lacaune ewes in 2018. www.mjksz.hu (accessed on 2020.10.01.)

ICAR (International Committee for Animal Recording), 2018. Section 16 - Guidelines for Performance and Recording in Dairy Sheep and Dairy Goats - Version February 2018. www.icar. org/Guidelines/16-Dairy-Sheep-and-Goats.pdf (accessed on 2020.10.01.)

Keszthelyi T., Maros K., 1992. Moving order in different group sizes of milking ewes. Appl. Anim. Behav. Sci. 35, 181-188, https:// doi.org/10.1016/0168-1591(92)90008-Y

Mačuhová L., Tančin V., Mačuhová J., Uhrinčat' M., Hasoňová L., Margetínová J., 2017. Effect of ewes entry order into milking parlour on milkability and milk composition. Czech J. Anim. Sci. 62, 392-402, https://doi.org/10.17221/11/2016-CJAS

Makovický P., Makovický P., Nagy M., Rimárová K., Diabelková J., 2014. Genetic parameters for somatic cell count, logscc and somatic cell score among breeds: Improved Valachian, Tsigai, Lacaune and their crosses. Acta Vet. 64, 386-396, https://doi. org/10.2478/acve-2014-0037 
Makovický P., Margetín M., Makovický P., Nagy M., 2019. Machine milkability of East Friesian and Lacaune dairy sheep. Ind. J. Anim. Sci. 89, 686-691

Marie C., Bocquier F., Barillet F., 1996. Effect of milk yield merit on components of feed efficiency of Lacaune dairy ewes (in French: Influence du potentiel laitier sur les composantes de l'efficacité alimentaire de brebis Lacaune). Ren. Rech. Ruminants 3, 297-300

Margetín M., Oravcová M., Margetínová J., Vavrišínová K., Janíček M., 2020. The influence of lamb rearing system on ewe milk and lamb growth traits in dairy sheep. J. Anim. Feed Sci. 29, 1, 27-34, https://doi.org/10.22358/jafs/118129/2020

Margetínová J., Brouček J., Apolen D., Mihina Š, 2003. Relationship between age, milk production and order of goats during automatic milking. Czech J. Anim. Sci. 48, 257-264

Murray T.L., Blache D.B., Bencini R., 2009. The selection of dairy sheep on calm temperament before milking and its effect on management and milk production. Small Rumin. Res. 87, 4549, https://doi.org/10.1016/j.smallrumres.2009.10.005

Nedeva I., Slavov T., Varlyakov I., Radev, V., Panayotov D., Nedelkov K., 2019. Behavior of Lacaune sheep in a milking parlour. Bulg. J. Agric. Sci. 25, Suppl. 3, 74-80

Oravcová M., Margetín M., Peškovičová D., Daňo J., Milerski M., Hetényi L., Polák P., 2006. Factors affecting milk yield and ewe's lactation curves estimated with test-day models. Czech J. Anim. Sci. 51, 483-490, https://doi.org/10.17221/3968-CJAS

Oravcová M., Margetín M., Peškovičová D., Daňo J., Milerski M., Hetényi L., Polák P., 2007. Factors affecting ewe's milk fat and protein content and relationships between milk yield and milk components. Czech J. Anim. Sci. 52, 189-198, https://doi. org/10.17221/2274-CJAS

Oravcová M., Mačuhová L., Tančin V., 2018. The relationship between somatic cells and milk traits, and their variation in dairy sheep breeds in Slovakia. J. Anim. Feed Sci. 27, 97-104, https://doi. org/10.22358/jafs/90015/2018

Othmane M.H., Carriedo J.A., De La Fuente L.F., Primitivio F., 2002. Factors affecting test-day milk composition in dairy ewes, and relationships amongst various milk components. J. Dairy Res. 69, 53-62, https://doi.org/10.1017/S0022029901005234
Pajor F., Murányi A., Szentléleki A., Tőzsér J., Póti P., 2010. Effect of temperament of ewes on their maternal ability and their lambs' postweaning traits in Tsigai breed. Arch. Anim. Breed. 53, 465-474, https://doi.org/10.5194/aab-53-465-2010

Park Y.W., Juárez M., Ramos M., Haenlein G.F.W., 2006. Physicochemical characteristics of goat and sheep milk. Small Rumin. Res. 68, 88-113, https://doi.org/10.1016/j. smallrumres.2006.09.013

Polikarpus A., Kaart T., Mootse H., De Rosa G., Arney D., 2015. Influences of various factors on cows' entrance order into the milking parlour. Appl. Anim. Behav. Sci. 166, 20-24, https:// doi.org/10.1016/j.applanim.2015.02.016

Robles Jimenez L.E., Angeles Hernandez J.C., Palacios C., Abecia J.A., Naranjo A., Osorio Avalos J., Gonzalez-Ronquillo M., 2020. Milk production of Lacaune sheep with different degrees of crossing with Manchega sheep in a commercial flock in Spain. Animals 10, 520, https://doi.org/10.3390/ani10030520

Szentléleki A., Nagy K., Széplaki K., Kékesi K., Tőzsér J., 2015. Behavioural responses of primiparous and multiparous dairy cows to the milking process over an entire lactation. Ann. Anim. Sci. 15, 185-195, https://doi.org/10.2478/aoas-20140064

Tóth G., Póti P., Abayné H.E., Gulyás L., Bodnár Á., Pajor F., 2017a. Effect of temperament on milk production, somatic cell count, chemical composition and physical properties in Lacaune dairy sheep breed. Mljekarstvo 67, 261-266, https://doi. org/10.15567/mljekarstvo.2017.0403

Tóth G., Póti P., Tokár A., Abayné H.E., Tőzsér J., Pajor F., 2017b. Effect of certain factors on milk production in Lacaune ewes (In Hungarian: Lacaune anyajuhok tejtermelését befolyásoló egyes tényezők vizsgálata). Állatteny. Takarm. 66, 240-245

Villagrá A., Balasch S., Peris C., Torres A., Fernández N., 2007. Order of sheep entry into the milking parlour and its relationship with their milkability. Appl. Anim. Behav. Sci. 108, 58-67, https:// doi.org/10.1016/j.applanim.2006.11.016

Wasilewski A., 1999. Demonstration and verification of a milking order in dairy sheep and its extent and consistency. Appl. Anim. Behav. Sci. 64, 111-124, https://doi.org/10.1016/S01681591(99)00032-5 